\title{
Bullying as a Socially Dangerous Act: Statistical Analysis and Proposals for the Criminalization of Bullying
}

\author{
Ganna Sobko *[0000-0002-5938-3400], Alla Bochevar [0000-0002-7582-0316] \\ Odesa State University of Internal Affairs, Odessa, Ukraine \\ *sobkoganna1984@ukr.net
}

\begin{abstract}
The article is focused on the analysis of criminological problems in relation to the conditions and causes of bullying, as well as the victimological component of this anti-social phenomenon. The age and characteristics of victims who suffer from bullying are analyzed. How the environment and family upbringing affect the further behavior of the bully and the victim. The types of bullers, witnesses to bullying, and places where bullying occurs were examined. Further consideration was aimed at the analysis of the socially dangerous act from different sides (from teachers and children). On the basis of the conducted questionnaire survey that took place among teachers of secondary educational institutions and directly among students of secondary educational institutions and students of higher educational establishments who are under 18 years old, amendments to the criminal legislation of Ukraine are proposed.
\end{abstract}

Keywords: bullying, victim, prevention, responsibility, violence, mental abuse, punishment.

\section{INTRODUCTION}

As a consequence of severe mental abuse, parents (or persons in loco parentis) ruin the life of a teenager, who in adulthood realizes himself through criminal elements, by subjecting himself to the will of another person and the like.

In order to establish the causes of criminal offenses, the researchers conducted an examination, during which the entire life history of each researcher was studied, beginning with the pregnancy of the mother and ending with the study of the psychological state of the accused during the examination. According to the results of the study, it was established that most of the violent murderers have psychological trauma acquired in childhood, due to the rejection of the child, authoritarian style of upbringing, disregard for the needs, and it was these ways of upbringing that played a decisive role in the future of these people. Because, as a rule, the subjects of criminal offenses are persons with low self-esteem and high levels of anxiety, a desire to assert themselves, as well as those who were emotionally unhappy in childhood or suppressed by overbearing parents.

That is why, in the author's opinion, mental abuse of a child is one of the deep factors in the formation of the subject of a criminal offence. However, it is impossible to unequivocally conclude that all criminals were subjected to mental abuse in childhood. There are cases where criminals grow up in normal families where no violence, including mental abuse, has ever been applied to children. Teenagers grow up in a psychologically healthy climate, with normal attitudes, and then all of a sudden they turn into a monster who commits grave or especially grave criminal offenses.

The famous Canadian criminal psychologist Robert D. Hare described cases in which families raise a "psychopath child" who displays a callous attitude to everyone and everything around him. Up to a certain period the criminal potential of such a person is in latent form, but at some point, a seemingly attractive boy or nice girl commits a felony and particularly serious crime [1, p. 123].

The fact is that a criminal is formed not only by upbringing, social ties, but also by the so-called psychopathological aggravation, which manifests itself as a hereditary factor, that is, when parents do not use violence against a child, but genetically pass on such a gene to him. We live in a society where we can constantly feel violence, if not at home, then outside it (at work, in the collective, on the street) and if a person is raised in accordance with social and moral standards, he is able to survive and adapt to the situation [2-4]. But it is more 
difficult for a person whose propensity for violence is genetically transmitted, so without a proper upbringing, a criminal can form. In addition, factors such as early central nervous system lesions, intrauterine infections, birth traumas, cranial traumas during life can work.

In view of the above, the question arises as to whether peer bullying (bullying, taunting, teasing, images) affects the formation of personality, its victimization or criminal intentions towards a minor [5, p. 88-104.]

Bullying is abusive behavior, aggressive harassment of one team member (school, student or professional) by other team members or part of the team [6].

Bullying should be understood as the systematic physical (beatings, etc.) or psychological impact (which is manifested by threats, humiliation, taunts, blackmail, etc.) on the victim. As a consequence of inflicting bodily injury (battery), it is possible to hold a person liable, while it is much more difficult to hold a person liable for committing emotional bullying.

\section{RESEARCH ANALYSIS}

One of the main preconditions that prevent aggressors from being held accountable is their age. According to the current legislation of the Ukraine, criminal responsibility begins at the age of 16 , in the case of committing criminal offenses under part 2 of article 22 of the Criminal Code of the Ukraine from the age of 14 , however, psychological and emotional impact does not fall under this category.

In 2018 the Verkhovna Rada of Ukraine adopted the Law of Ukraine "On amendments to some legislative acts of Ukraine on combating bullying" № 2657-VIII of 18.02.2018, which entered into force in 2019, which defines bullying as an administrative offence [7]. Article 1734 of the CAOAP defines that bullying is the actions of participants in the educational process, which consist of psychological, physical, economic, sexual violence, including the use of electronic communications, committed against a minor or a juvenile or by such person in relation to other participants in the educational process, as a result of which there could be or was harm to the mental or physical health of the victim [8].

The peculiarity of bullying is systematic (recurrence) of the act and the presence of consequences - causing harm (physical or mental health), including humiliation, fear, submission of the victim to the interests of the bully, and (or) causing social isolation of the victim. However, it is rather difficult to establish the degree of harm caused to the mental health of the minor.

It is necessary to distinguish between bullying:

1) direct - when a teenager is beaten, insulted, teased, damaged things, etc., such bullying is typical for younger children;

2) indirect - spreading rumors, gossip, boycotting, shunning, manipulating friendship, characteristic of middle and high school students;

3) cyberbullying - bullying using modern technology, e-mail, social networks, etc., which emerged as a result of scientific and technological progress and the prevalence of the Internet [9].

And boys more often become victims of physical bullying when things are taken away from them, damaged, threatened or forced to do certain things. While girls, as a rule, suffer from gossip and rumors, indecent expressions, etc. $[10$, p. 795$]$

On the basis of the subjective composition we should define - the bully (the person who carries out the bullying), the victim (the victim) and witnesses. Bullies quite often have personality traits, and have a number of complex social risks. They are characterized by impulsiveness, they are easily frustrated, they have difficulty following rules, they demonstrate rudeness and lack of compassion for the victim, and they are inherently aggressive. Such adolescents are good at navigating emotions and mental states and are successful at manipulating children. The main motive of bullying is power, getting pleasure from the damage caused, suffering to others, including material benefits (money, cigarettes, other valuable things that are taken away from the victims) or psychological benefits (prestige, social status, etc.) [11].

Victims of bullying are by nature more sensitive, anxious, physically underdeveloped, whiny, have low self-esteem and few or no friends. The typical victim of bullying is a withdrawn child with behavioral problems, negative beliefs about themselves, and social difficulties. In fact, such characteristics can be both consequences of bullying and its prerequisites [10, p. 795].

Witnesses to bullying are the majority of bully participants, whose reactions are a very important element and even the smallest endorsement (a smile, etc.) of the witnesses serves as a reward for the bully. According to Canadian researchers, $68 \%$ of bullying witnesses were sympathetic to the victims, but less than half tried to help the victim. The social dilemma of bullying witnesses is whether to try to stop the bullying or to put themselves (the witness) in danger, thereby losing status in the children's group. This fear puts a barrier in protecting the victim of bullying or notifying their parents of the incident [12].

Besides, quite often in families of victims of bullying there is either domestic violence or hypertrophy, which feeds the defenselessness of a child. Children who initiate bullying are also quite often subjected to harsh treatment in the family [13].

Bullying (humiliation) in conditions of inequality is traditionally present in social relations, both vertical: parents - children; teacher - student; boss - subordinate, and horizontal: between colleagues, peers, spouses, etc. [14, p. 401-420]. 


\section{THE PURPOSE OF THE ARTICLE}

During the study of this topic we conducted a survey of 1570 minors (including 261 underage cadets and students of OSUIA, 329 underage students of law institutes of Odesa, 980 teenagers of secondary schools) and found that $60,5 \%$ of teenagers have never felt the mental abuse, but 32 , 95\% were subjected to such violence, which they felt as a victim of mental violence:

- At school - 34, 55\% of questioned teenagers, of which $18,25 \%$ experienced emotional violence against themselves, $16,15 \%$ - mental, $2,45 \%$ - physical, $2,15 \%$ sexual.

- Among peers - 30, 85\%, and among friends - 14, $95 \%$ of respondents felt that they were victims of mental violence, and when asked "Have you experienced pressure from classmates (classmates), which can be attributed to mental violence (bullying), 75, $4 \%$ of minors said that they have not experienced such violence. 57, 65\% of respondents indicated that their peers (classmates/classmates) had talked about committing mental violence against them. This difference in percentage indicates that teenagers did not answer the questions sincerely.

- At home - $14.08 \%$ of the surveyed adolescents. At the same time, $79.2 \%$ of minors live in a complete family (with two parents), 46, 95\% of respondents noted that in their families parents do not have conflicts, $29.16 \%$ of students noted that during conflicts parents quarrel and shout, and $21.45 \%$ do not talk to each other. After conflicts in $10,15 \%$ of minors parents try to vent their negative emotions on them, thereby using violence. However, $62.8 \%$ of the respondents never yelled, harassed, manipulated, humiliated, or blackmailed minors. However, 5, 85\% of students noted that parents told them that they wished that they (their children) had died or not been born at all. To the question "Did their parents ever use moral punishment on their children?" $40.1 \%$ said that they sometimes did, and $4.35 \%$ said they always did [15]. At the same time $45,1 \%$ of respondents believe that such punishment is fair. $73.5 \%$ of underage respondents reported they tried to defend themselves when violence was perpetrated against them. Given that COVID-19 forced children to stay home [16].

Returning to the bullying question, $31,15 \%$ of minors committed violence against someone. Based on this figure, $47 \%$ of juveniles committed mental violence $(5$, $9 \%$ committed physical violence, 5, 01\% committed sexual violence, and $4,25 \%$ said they committed physical and mental violence).

\section{THE MAIN MATERIAL}

It should be noted that according to the results of the questionnaire most of the minors are really guided in understanding mental violence, bullying, manipulation. More than $75 \%$ of parents surveyed conducted informational conversations about ways of protection from mental violence and $82,25 \%$ of respondents noted that in their educational institution (school, institute, technical school) there were seminars, lectures, trainings on formation of legal consciousness of protection from violence.

Taking into account the above-mentioned questionnaire data, bullying issues become relevant, since it was found that $80,35 \%$ of cases of mental violence (including bullying) take place in school, among friends and among peers. The lack of criminalization of mental violence (bullying, harassment, etc.) is a significant gap in the legislation, because, according to the author, the latter carries a significant danger to society, consisting in the consequences of violent mental influence, namely the violation of the normal bonds of the younger generation, the development of mental and psychiatric deviations of teenagers, thereby we can talk about the definition of the nation genocide, driving to suicide, committing murder (within self-defense, according to the victim.

At the same time, the stricter the punishment, the more likely the prevention of bullying. At the same time, if criminal liability for mental domestic violence is already defined by the Article $126^{1} \mathrm{CC}$ of Ukraine, and special units of law enforcement agencies have been created to combat such violence, the issue of mental violence among the younger generation is not sufficiently regulated [17].

That is why the question of criminalization of a deed arises, because between administrative and criminal responsibility there is one of the main differences as the gravity of the offense. After all, an administrative offense, unlike a criminal offense, does not carry a great danger to society, in connection with which the process of bringing to responsibility is simplified. At the same time for a criminal offence there is a more severe punishment than for an administrative offence.

To prevent bullying there should also be a comprehensive response to this type of mental violence involving the classroom teacher, the guidance counselor, the person acting as the guidance counselor. First and foremost, it is the responsibility of educational institutions not only to carry out the educational process, but also to shape and maintain the climate and atmosphere within the team. In cases where threats from adolescents are aggressive, violent and dangerous, it is necessary to conduct psychological work with such students, including informing the administration of the educational institution.

The research also included a survey of 234 teachers (including 35, 85\% of grade school teachers, 28, $2 \%$ of subject teachers, $23,15 \%$ of middle school teachers, 5 , $15 \%$ of high school teachers, $4 \%$ of psychologists, $2,5 \%$ of social pedagogues and 1, $15 \%$ of speech therapists). $58.95 \%$ of the respondents had encountered cases of child abuse in their professional activities. 
The study found that mental violence is usually committed against children $6-10$ years old $(38,75 \%), 10$ 14 years old $(30,65 \%)$, and $14-15$ years old $(15 \%)$. And in $73,5 \%$ of cases mental violence is committed in dysfunctional families where alcohol and other substances are abused, and families that have low incomes.

In regards to bullying, $51.5 \%$ of teachers witnessed bullying in school, and $52.95 \%$ of students turned to teachers for help and protection from peers. When asked who bullying is typically committed by, $47 \%$ of teachers reported that teenagers from dysfunctional families; $15 \%$ of teachers reported that bullying is committed by children from well-to-do families; $11,5 \%$ of respondents said that children from single-parent families; and 6,5\% said that children from large families.

At the same time, $91.5 \%$ of teachers believe that it is impossible to prevent bullying in school. However, $70.25 \%$ noted that it is possible to prevent bullying at school by joint efforts of administration, teaching staff, parents and students.

Based on the results of the questionnaire, it is clear that teachers consider it impossible to prevent bullying at school, at the same time, according to the author, it is the inaction of the educational institution that promotes bullying and it is the responsibility of the latter to organize the activities aimed at localizing and stopping the conflict situation between the students. For example, when a bully tries to demand something from the victim or tries to take it away by force. In this case it is almost impossible to bring a minor to responsibility, so with such students it is necessary to work with specialists and not to absolve themselves of responsibility. It is not uncommon for nonphysical violence to escalate to physical violence and for the victim to be bodily harmed. In that case, it will be easier to hold the bully accountable, for example, if the latter has caused serious bodily harm to another student (the victim), in which case he (the bully) will be held accountable if he is 14 years of age.

As a conclusion it should be noted that the teacher's behavior determines the subjective perception of the child's sense of safety at school, the teacher is a figure who can stop or support violence. The broadcasting of violence through the media, environmental hazards and society affect children's behavior, the risk of bullying increases in a socially disorganized environment with high levels of crowding, drinking and drug abuse.

\section{CONCLUSIONS}

Thus, summarizing the above, it should be noted that children are our future, so for the development of a legal, social and democratic Ukraine, public authorities should direct their political activity to ensure comprehensive measures on the issues of education, re-education, socialization of minors who are victims of domestic violence, including mental, were subjected to bullying (harassment) and take measures to counteract the commission of offenses by teenagers.

In view of what is proposed:

1. to create social centers for minors who are victims of mental abuse and need protection at the state and regional level. The purpose of such social centers will be conducting psychological and psychiatric correction of behavior, legal and educational work, as well as activities aimed at improving the knowledge and socialization of minors;

2. to introduce a state register of minors who are victims of mental violence, in which information about the use of at least one type of mental violence against a minor is entered. If there are three or more facts of the use of mental violence against minors, it is proposed to initiate the restriction or deprivation of parents (guardians, or persons replacing them) of parental rights;

3. to resolve at the legislative level the issue of providing social benefits to children who are victims of mental violence: 1) in the form of guaranteed priority accommodation and free accommodation in dormitories of educational institutions (technical schools, universities, etc.); 2) to allocate assistance to pay for educational services, etc.;

4. to solve at the legislative level the issues of employment of minors (for persons from 16 to 18 years old, in exceptional cases, with the consent of parents from 14 to 15 years, to perform work that is not harmful to health and does not disrupt the learning process, in their free time), since it is such employment has a socially useful, educational, at least not in large scale, but helps to solve material problems, stimulates educational work and organizes leisure time of youth. That is why, in the author's opinion, the state should direct its efforts to attract citizens with increased victimization to work, including minors, low-income and single-parent families, children from large families, children registered with law enforcement agencies;

5. to solve the issue of criminalization of bullying, namely to supplement the Criminal Code of Ukraine with the Article $126^{3}$ "Bullying", namely:

\section{Article 1263 "Bullying"}

1. "Bullying (bullying) committed by an organizer or active participant concerning the deliberate systematic commission of physical, psychological, emotional, sexual violence, including with the use of the global Internet (social networks, etc.) against a minor or a minor, if they caused grave consequences, -

shall be punished by imprisonment for a term of two to five years.

2. Actions defined in part one of the present article, committed by a teacher (teacher, pedagogue, educational institution administration, social pedagogue) towards a 
minor, including who instigates, organizes committing bullying towards a minor or a juvenile -

shall be punished by imprisonment for a term of five to seven years with deprivation of the right to hold certain positions or engage in certain activities for up to five years".

Note. Severe consequences should be understood as the death of one or more people, including incitement to suicide, significant damage to the health of a minor (namely life-threatening, loss of vision, speech, hearing or any organ or loss of organ function; pregnancy termination, mental disorder, drug or substance abuse diseases; permanent disfigurement of a person or longterm health disorder), property damage on a large or especially large scale, etc. [11]

\section{REFERENCES}

[1] Olweus, D. (1993), Bullying at school: What we know what we can do. Wiley-Black-well, N.Y., USA.

[2] Korystin, O.Ye. and Sobko, H.M. (2019), "Methodological principles of understanding the phenomenon of "violence" in criminal law", Nauka $i$ Pravookhorona, no. 2 (44), pp. 139-148, DOI: $10.36486 / \mathrm{np} .2019 .2$

[3] Korystin, O.Ye. (2020), Chapter 4. State Legal Police of Scientific Prediction. Public administration in the digital economy, monograph, Tallinn, Scientific Center of Innovative Researches OU, DOI: 10.36690 PADE

[4] Korystin, Oleksandr and Svyrydiuk, Nataliia (2021), "Formation of security competences in law enforcement activities", Nauka i Pravookhorona, vol. 1 (51), pp. 191-198, DOI: $10.36486 / \mathrm{np} .2021 .1(51) .20$

[5] Chen, M. and Chan, K.L. (2015), "Effects of Parenting Programs on Child Maltreatment Prevention: A Meta-Analysis", Trauma, Violence, \& Abuse, vol. 17, iss. 1, pp. 88-104.

[6] Bullying (from English - bully, intimidate), available at: https://wiki.legalaid.gov.ua/index.php

[7] "The Law of Ukraine On Amendments to Certain Legislative Acts of Ukraine on Countering Bullying" (2019), Bulletin of the Verkhovna Rada, no. 5, art. 33, available at: https://zakon.rada.gov.ua/laws/show/2657-19\#Text

[8] Code of Ukraine on Administrative Offenses (Articles 1 - 212-24) (Article 213 - Article 330) (Information of the Verkhovna Rada of the Ukrainian SSR (VVR) 1984, appendix to № 51, Article 1122) \{Entered into force by the Resolution of the Verkhovna Rada of the Ukrainian SSR №
8074-10 from 07.12.84, VVR 1984, supplement to № 51, art.1123\}, available at: https://zakon.rada.gov.ua/laws/show/8073110\#Text

[9] Suratno, A. \& Aydawati, E.N. (2017), "Exploring Students Perception and ICT Use in Indonesian High Schools", Celt: A Journal of Culture, English Language Teaching \& Literature, vol. $16(2)$, p. 177.

[10] Canada's family violence initiative: partnerships, available at: https://www.scielo.br/scielo.php?script=sci_arttext \&pid=S0102311X1994000500017\&lng=en\&nrm=iso., c. 795

[11] Sobko, G. (2020), "Criminal law and criminological basis for combating mental violence", The dissertation, Criminal law, available at: https://dndi.mvs.gov.ua/files/pdf/dissertation_Sobk o_G_M.pdf

[12] Semerci, A. \& Aydın, M.K. (2018), "Examining High School Teachers' Attitudes towards ICT Use in Education", International Journal of Progressive Education, vol. 14 (2), pp. 93-105, DOI: 10.29329/IJPE.2018.139.7

[13] Robles, Ava Clare Marie O. (2013), "The Use of Educational Web Tools: An Innovative Technique in Teacher Education Courses", International Journal of Modern Education and Computer Science, vol. 5, no.2, pp. 34-40, DOI: $10.5815 /$ ijmecs.2013.02.05

[14] Wikström, P.-O.H. Tseloni, A. and Karlis, D (2011), "Do People Comply with the Law because they Fear Getting Caught?", European Journal of Criminology, vol. 8, iss. 5, pp. 401-420.

[15] Imrus Salehina, Sadia Tamim Dipa, Iftakhar Mohammad Talhaa, Ibrahim Rayhana and Kanij Fatema Nammi (2021), "Impact on Human Mental Behavior after Pass through a Long Time Home Quarantine Using Machine Learning” International Journal of Education and Management Engineering, vol. 1, pp. 41-50, DOI: 10.5815/ijeme.2021.01.05

[16] Mirza Waseem Hussain, Tabasum Mirza, Malik Mubasher Hassan (2020), "Impact of COVID-19 Pandemic on the Human Behavior", International Journal of Education and Management Engineering, vol. 5, pp. 35-61, DOI: 10.5815/ijeme.2020.05.05

[17] Article $126^{1}$, Domestic violence, available at: https://zakon.rada.gov.ua/laws/show/2341-14\#Text 